\title{
Szelén fitoextrakciója és mikrobacsoportok előfordulása szennyezett talajokban
}

\author{
${ }^{1 a}$ SIMON LÁSZLÓ, ${ }^{2}$ BIRÓ BORBÁLA, ${ }^{3}$ SZÉLES ÉVA és \\ ${ }^{1 b}$ BALÁZSY SÁNDOR
}

\begin{abstract}
${ }^{1}$ Nyíregyházi Főiskola, ${ }^{a}$ Táj- és Környezetgazdálkodási Tanszék, ${ }^{b}$ Biológia Intézet, Nyíregyháza; ${ }^{2}$ MTA Talajtani és Agrokémiai Kutatóintézet, Budapest és ${ }^{3}$ Debreceni Egyetem, Agrártudományi Centrum, Élelmiszertudományi és Minőségbiztositási Tanszék, Debrecen
\end{abstract}

\section{Bevezetés}

A felszíni talajok szeléntartalmának világátlaga $0,33 \mathrm{mg} \cdot \mathrm{kg}^{-1}$. A talajokban a szelénvegyületek oldhatósága, mobilitása általában kicsi, ezért a legtöbb országban (így Magyarországon is) a termények és takarmányok szeléntartalma a kívánatosnál kisebb. A szemiarid, illetve arid övezetekben azonban erősen meszes vagy rossz vízgazdálkodású, ún. szelenifer talajok is a találhatók (pl. az Egyesült Államokban, Kaliforniában), amelyek feltalajának természetes eredetủ szeléntartalma veszélyesen nagy, és jóval meghaladja a már kritikusnak tartott $2 \mathrm{mg} \cdot \mathrm{kg}^{-1}$ értéket. Szelén kerülhet a talajokba, felszíni vizekbe antropogén hatásra is, pl. szennyvíziszapkijuttatással, műtrágyákkal, szerves trágyákkal, mesterséges szelénkijuttatással, ércfeldolgozással, az olajfinomítás melléktermékeivel és a szálló pernyékkel. A szelén az állati (és emberi) szervezet számára esszenciális mikroelem, legtöbbször a hiánya okoz gondot. Az élettani minimumszükséglet és a már toxikus koncentráció közötti intervallum azonban nagyon szük, így a talajokban található szeléntartalom a toxikusság, illetve a környezetszennyezés miatt is nagyon fontos (ADRIANO, 2001; BARCELEOUX, 1999; KABATA-PENDIAS \& Pendias, 2001; KÁDÁR, 1999; SZABÓ et al., 1993; TERRY et al., 2000).

A talajban a szelén különféle vegyértékủ formákban fordul elö, melyek aránya és koncentrációja elsősorban a pH-tól és a redoxviszonyoktól függ. A növények számára jól felvehető, mobilis szelenátok $\left(\mathrm{Se}^{6+}\right)$ csak jól szellőzött, lúgos talajokban fordulnak elő. A szelenitek $\left(\mathrm{Se}^{4+}\right)$ mérsékelten mobilisak és a jó vízgazdálkodású semleges vagy savanyú kémhatású talajokban találhatóak meg. Mivel a talajban a szelenitek könnyen adszorbeálódnak az Al- és Fe-oxidokon és a szerves anyagon, a növények számára általában kevésbé felvehetőek (ADRIANO, 2001; KABATAPendias \& PENDias, 2001; KÁdÁr, 1999; Terry et al., 2000). A szelenátokat aktív módon, kénanyagcseréjük során veszik fel a növények, míg a szeleniteket

Postai cím: SIMON LÁSZLÓ, Nyíregyházi Főiskola, Müszaki és Mezőgazdasági Főiskolai Kar Táj- és Környezetgazdálkodási Tanszék, 4401 Nyíregyháza, Pf. 166.E-mail: simon1@ nyf.hu 
passzív módon akkumulálják (TERRY et al., 2000). A legtöbb mezőgazdasági növény szeléntartalma kisebb, mint $1 \mathrm{mg} \cdot \mathrm{kg}^{-1}$ (szárazanyagra számítva), élelmiszereinké alig haladja meg a $0,1 \mathrm{mg} \cdot \mathrm{kg}^{-1}$-ot (ADRIANO, 2001; BARCELEOUX, 1999; Kabata-Pendias \& Pendias, 2001; Terry et al., 2000). A káposztafélék (Brassicaceae) azonban - köztük a szareptai mustár (Brassica juncea L.) - néhány száz milligramm szelén akkumulációjára is képesek egy gramm szárazanyagra számítva, ha szelénnel mérsékelten szennyezett talajokon termesztjük őket (BAÑUELOS \& MEEK, 1990; BAÑUELOS et al., 1990; ZAYED et al., 1998).

A növényeknek tehát kulcsszerepük van a táplálékláncba kerülő szelén közvetítésében. Szelénhiányos területeken, szelénpótlás esetén az elemet jól akkumuláló fajokkal szelént juttathatunk az állati és emberi szervezetbe (BARCELEOUX, 1999; HEGEDÜS et al., 2005; TERRY et al., 2000). Másrészt a talajok szelénszennyeződését növényekkel is csökkenthetjük az ún. fitoremediáció során, amikor növényekkel, illetve a velük társult mikroorganizmusok segítségével tisztítjuk meg a környezeti elemeket a szervetlen vagy szerves szennyezőanyagoktól (SIMON, 2004). Fitoextrakcióról akkor beszélünk, ha a talajból a nehézfém-szennyeződések a növények könnyen betakarítható szerveibe kerülnek át. Fitovolatizációnak nevezzük azt a folyamatot, amikor a növények, illetve a rizoszférájukban található mikroorganizmusok a szervetlen szelént illékony szelénvegyületekké, elsősorban dimetilszeleniddé alakítják át, és így csökkentik a talajban lévő szeléntartalmat, illetve a szelén fitotoxikus tüneteit (DE SOUZA et al., 1999; TERRY \& BAÑUELOS, 2000; TERRY et al., 2000). A rizoszférában található mikroorganizmusok közül ilyen tevékenység kifejtésére elsősorban az adott szennyezővel szemben toleráns, vagy egyéb hasznos tevékenységre (pl. növényi hormontermelésre) is képes mikrobák használhatók (ZHANG \& CHASTEEN, 1994; XIE et al., 1996; VIVAS et al., 2003).

Megvizsgáltuk, hogy szelenátokkal vagy szelenitekkel mesterségesen szennyezett talajokból a szareptai mustár, takarmányretek és a lucerna mennyi szelén fitoextrakciójára képes. Tanulmányoztuk továbbá, hogy ezekben a szelénnel szenynyezett talajokban milyen mikrobacsoportok vannak jelen, és azok között vannak-e olyan fajok, melyekröl feltételezhetö, hogy a rizoszférában serkentik a szelén fitoextrakcióját, illetve fitovolatizációját.

\section{Anyag és módszer}

Tenyészedény-kísérlet. - A szennyezetlen Ramann-féle rozsdabarna erdőtalaj (vályogos homok, leiszapolható rész 15,8\%; $\mathrm{pH}_{\mathrm{KCl}} 6,6$; humusztartalom 1,3\%; Térték $18,1 \mathrm{cmol}_{\mathrm{c}} \cdot \mathrm{kg}^{-1}$ ) a Nyíregyházi Főiskola Rákóczi úti bemutatókertjének legfelső, 0-20 cm-es rétegéből származott. A $2 \mathrm{~mm}$-es szitán átbocsátott, megfelelően homogenizált, légszáraz talajmintákat $2,5 \mathrm{mg} \cdot \mathrm{kg}^{-1}$ szelénnel szennyeztük oly módon, hogy a vékonyan szétterített talajra nátrium-szelenit $\left(\mathrm{Na}_{2} \mathrm{SeO}_{3} \cdot 5 \mathrm{H}_{2} \mathrm{O}\right.$, Fluka, Németország) vagy nátrium-szelenát $\left(\mathrm{Na}_{2} \mathrm{SeO}_{4}\right.$, Fluka, Németország) oldatokat permeteztünk, majd a talajt alaposan összekevertük. A kontrolltalaj nem részesült ilyen kezelésben. Fényszobás, tenyészedény-kísérletet állítottunk be 4 ismétléssel 
szareptai mustárral (Brassica juncea L. Czern., cv. Negro Caballo) és takarmányretekkel (Raphanus sativus L. convar. oleiformis Pers., cv. Leveles olajretek). Az 1-1 kg kontroll- vagy szelénsókkal kezelt talajt tartalmazó tenyészedényekben 2-5 növényt neveltünk. A kísérlet időtartama alatt a megvilágítást (naponta 5000 lux 10 órán keresztül) fénycsövekkel szabályoztuk, a hömérséklet nappal $24-26^{\circ} \mathrm{C}$, éjszaka $17-18{ }^{\circ} \mathrm{C}$, a relatív páratartalom $40-50 \%$ volt. A növényeket hetente 3 alkalommal desztillált vízzel öntöztük, a szántóföldi vízkapacitás eléréséig (tömegállandóságig). A kísérlet időtartama alatt 2 alkalommal juttattunk a talajba $40 \mathrm{mg} \cdot \mathrm{kg}^{-1}$ nitrogént $\mathrm{NH}_{4} \mathrm{NO}_{3}$ oldat formájában. A kísérletet 6 hét eltelte után bontottuk. A tenyészedények talajának 4 ismétléssel történt megmintázása után a növények gyökerét és hajtását csapvízzel, majd háromszor váltott desztillált vízzel gondosan megmostuk, megszárítottuk $\left(40^{\circ} \mathrm{C}, 12\right.$ óra) és megdaráltuk $(<1 \mathrm{~mm})$. A növény- és talajminták feltárása (cc. $\mathrm{HNO}_{3}+$ cc. $\mathrm{H}_{2} \mathrm{O}_{2}$ ) után elemösszetételüket ICP-OES (Optima 3300 DV, Perkin-Elmer, USA) vagy ICP-MS (X7 series, Thermo Elemental, UK) technikával határoztuk meg 4 ismétléssel a Debreceni Egyetem Agrártudományi Centrumában (KováCs et al., 2000).

A koncentrációhányadosokat a növényi szervekben és a talajban mért szeléntartalmakat elosztva számoltuk ki. A transzport indexeket a hajtásban és a teljes növényben mért szelénmennyiségek hányadosának százszoros értékeként számítottuk ki (SIMON et al., 2003).

A kísérlet befejezésekor a növények gyökerére tapadt talaj (rizoszféra talaj) mikrobaközösségeit is megvizsgáltuk oly módon, hogy a légszáraz talajból (4 ismétlésböl) 1-1 g-os átlagmintákat képeztünk. $1 \mathrm{~g}$ légszáraz talajt $100 \mathrm{~cm}^{3}$ steril $0,85 \%$-os $\mathrm{NaCl}$ oldatban 20 percig rázattunk. Hígítási sor után az oldatokból $50 \mu \mathrm{l}-\mathrm{t}$ Nutrient és King B táplemezekre szélesztettünk, melyet 48 óráig $26^{\circ} \mathrm{C}$-on inkubáltunk. A kitenyésztett mikroorganizmusokat nemzetség szintig biokémiai módszerekkel (Gram-festés, oxidáz-kataláz reakciók, savképzés stb.), a fajokat $\mathrm{API}^{\circledR}{ }^{\circledR}$-tesztekkel azonosítottuk, és meghatároztuk százalékos előfordulási arányukat (VINCZE et al., 1994).

Szabadföldi kísérlet. - A 13 különféle nehézfém-szennyezést tanulmányozó nagyhörcsöki szabadföldi kisparcellás tartamkísérletben 1991-ben a mészlepedékes csernozjom talajt (vályog, $\mathrm{pH}_{\mathrm{KCl}} 7,1-7,4$; leiszapolható rész 75-85\%; humusz 3$3,5 \%$; $\mathrm{CaCO}_{3}$ ekvivalens 3-5\%; T-érték $30 \mathrm{cmol}_{\mathrm{c}} \cdot \mathrm{kg}^{-1}$ ) 0, 30, 90, 270 és $810 \mathrm{~kg} \cdot \mathrm{ha}^{-1}$ szelénadagokkal szennyezték nátrium-szelenit $\left(\mathrm{Na}_{2} \mathrm{SeO}_{3}\right)$ formájában (KÁDÁR, 1999; NÉMETH \& KÁDÁR, 2005). 2005-ben a kontroll- és szelénnel kezelt parcellákon második éve lucernát (Medicago sativa L., cv. Anna) termesztettek. 2005 őszén a kísérleti parcellák átlós bejárásával 10-10 helyröl történt mintavétellel 2 átlagmintát vettünk a lucernahajtásokból, illetve 20-20 0-20 cm-es mélységből történt leszúrásból 2 átlagmintát képeztünk a talajmintákból. A minták előkészítése és elemanalízise a fent leírt módon történt. A növényminták elemanalízisét az MTA Talajtani és Agrokémiai Kutatóintézetben végezték ICP-OES technikával.

A mikrobiológiai vizsgálatokat a 270 és $810 \mathrm{~kg} \cdot \mathrm{ha}^{-1}$ szelénkezelést kapott parcellák talajából végeztük. A különféle mikrobacsoportok (heterotrófok, mikroszkopikus gombák, sugárgombák, valamint a spóraképzők) kitenyészthető sejtszámát (abundanciáját) szelektív táplemezek segítségével a megfelelő talajhígításokból 
határoztuk meg (ANGERER et al., 1998). A heterotrófokat és a spóraképzőket Nutrient-táplemezeken (utóbbiakat 10 perces $80{ }^{\circ} \mathrm{C}$-os vízfürdős kezelés után), a sugárgombákat Ashby-lemezeken, a mikroszkopikus gombákat pedig Martinagaron határoztuk meg (SZEGI, 1976). A szelén-toleráns mikrobák részarányát szelektív, $0 ; 0,3 ; 1,1 ; 3,4$ és $10 \mathrm{mM}$ Na-szelenitet tartalmazó táptalajokon ellenőriztük. A mikrobacsoportoktól függő 1 napos vagy 1 hetes inkubáció után a kifejlődött telepeket megszámoltuk, majd a kapott sejtszámokat $1 \mathrm{~g}$ száraz talajra vonatkoztattuk. A domináns mikrobafajok azonosítása a tenyészedény-kísérletben leírt módon történt.

Statisztikai analizis. - A kísérleti adatok feldolgozása és rendszerezése Microsoft Excel programmal történt. A mérési adatok statisztikai elemezését egyváltozós varianciaanalízissel, Tukey-féle b-teszttel végeztük, SPSS programot alkalmazva. Az adatok statisztikai analízise után a mikrobaszámok log-transzformált értékeit közöljük.

\section{Eredmények és értékelésük}

A tenyészedényes fényszobás kísérletben a Na-szelenittel $\left(2,5 \mathrm{mg} \mathrm{Se} \cdot \mathrm{kg}^{-1}\right)$ szennyezett barna erdőtalajból a szareptai mustár hajtása $21,1 \mu \mathrm{g} \cdot \mathrm{g}^{-1}$, a takarmányreteké pedig $34,9 \mu \mathrm{g} \cdot \mathrm{g}^{-1}$ szelént akkumulált. Na-szelenát $\left(2,5 \mathrm{mg} \mathrm{Se} \cdot \mathrm{kg}^{-1}\right)$ kijuttatás esetén ezek az értékek jelentősen megemelkedtek és a szareptai mustár, illetve a takarmányretek hajtásában elérték az 585, ill. $684 \mu \mathrm{g} \cdot \mathrm{g}^{-1}$-ot (1. táblázat). Igazolódott tehát, hogy a növények a talajban lévő szelenátokból - aktív transzporttal - jóval több szelént szállítanak át a föld feletti szerveikbe, mint passzív akkumulációval a

\section{1. táblázat}

Szareptai mustár és takarmányretek szelénakkumulációja és szárazanyag-hozama (tenyészedény-kísérlet, Nyíregyháza, 2006)

\begin{tabular}{|c|c|c|c|c|}
\hline \multirow{2}{*}{$\begin{array}{c}\text { (1) } \\
\text { Kezelések }\end{array}$} & \multicolumn{2}{|c|}{$\begin{array}{c}\text { (2) } \\
\text { Szareptai mustár }\end{array}$} & \multicolumn{2}{|c|}{$\begin{array}{c}\text { (5) } \\
\text { Takarmányretek }\end{array}$} \\
\hline & $\begin{array}{c}\text { (3) } \\
\text { Gyökér }\end{array}$ & $\begin{array}{c}(4) \\
\text { Hajtás }\end{array}$ & $\begin{array}{c}\text { (3) } \\
\text { Gyökér }\end{array}$ & $\begin{array}{c}(4) \\
\text { Hajtás }\end{array}$ \\
\hline \multicolumn{5}{|c|}{ A. Szelénakkumuláció ( $\mu g$ Se $\cdot g^{-1}$ szárazanyag) } \\
\hline a) Kontroll & $0,46^{\mathrm{a}}$ & $0,33^{\mathrm{a}}$ & $0,19^{\mathrm{a}}$ & $0,94^{\mathrm{a}}$ \\
\hline b) $2,5 \mathrm{mg} \cdot \mathrm{kg}^{-1} \mathrm{Na}$-szelenit & $34,0^{\mathrm{a}}$ & $21,1^{\mathrm{a}}$ & $51,3^{\mathrm{a}}$ & $34,9^{\mathrm{a}}$ \\
\hline c) $2,5 \mathrm{mg} \cdot \mathrm{kg}^{-1} \mathrm{Na}$-szelenát & $694^{\mathrm{b}}$ & $585^{\mathrm{b}}$ & $683^{\mathrm{b}}$ & $684^{\mathrm{b}}$ \\
\hline \multicolumn{5}{|c|}{ B. Szárazanyag (g·növény $\left.{ }^{-1}\right)$} \\
\hline a) Kontroll & $0,07^{\mathrm{a}}$ & $0,89^{\mathrm{a}}$ & $0,02^{\mathrm{a}}$ & $0,30^{\mathrm{a}}$ \\
\hline b) $2,5 \mathrm{mg} \cdot \mathrm{kg}^{-1} \mathrm{Na}$-szelenit & $0,06^{\mathrm{a}}$ & $0,72^{\mathrm{ab}}$ & $0,02^{\mathrm{a}}$ & $0,40^{\mathrm{b}}$ \\
\hline c) $2,5 \mathrm{mg} \cdot \mathrm{kg}^{-1} \mathrm{Na}$-szelenát & $0,01^{\mathrm{b}}$ & $0,16^{\mathrm{b}}$ & $0,01^{\mathrm{b}}$ & $0,14^{\mathrm{c}}$ \\
\hline
\end{tabular}

Megjegyzés: Varianciaanalízis. Tukey-féle b-teszt $(\mathrm{n}=4)$. Az azonos betűindexet kapott oszlopok értékei szignifikánsan nem különböznek egymástól $(\mathrm{P}<0,05)$ 
szelenitekből. Szintén igazoltuk, hogy a szareptai mustár már mérsékelt talajszenynyezés esetén is jelentös mennyiségủ szelént halmoz fel hajtásában (BAÑUELOS \& MEEK, 1990; BAÑUELOS et al., 1990; ZAYED et al., 1998). Ez a megfigyelés az ugyancsak a káposztafélék közé tartozó (korábban mások által ilyen szempontból nem vizsgált) takarmányretek esetén is igaznak bizonyult. A transzport indexek alapján megállapítottuk, hogy a szareptai mustár szelenit-kijuttatás esetén a felvett szelén 38\%-át, szelenátkezelés esetén pedig 49\%-át szállítja át a hajtásába, mely a fitoextrakció során könnyen betakarítható. Takarmányretek esetén ezek az értékek nagyon hasonlóak; 40, illetve 48\%-osak voltak.

A kísérlet befejezésekor a szareptai mustár talajában ICP-MS technikával a következő átlagos ,„̈sszes” (cc. $\mathrm{HNO}_{3}+\mathrm{cc} . \mathrm{H}_{2} \mathrm{O}_{2}$-oldható) szeléntartalmakat mértük: $9,7 \mu \mathrm{g} \cdot \mathrm{kg}^{-1}$ (kontroll); $713 \mu \mathrm{g} \cdot \mathrm{kg}^{-1}$ (Na-szelenit kezelés) és $532 \mu \mathrm{g} \cdot \mathrm{kg}^{-1}$ (Na-szelenát kezelés). Takarmányretek kultúra esetén ezek az értékek $<1,710$ és $508 \mu \mathrm{g} \cdot \mathrm{kg}^{-1}$ voltak a kontroll-, Na-szelenit- és Na-szelenát kezelésekben. Az adatok szintén alátámasztják, hogy a talaj szelenátkezelése esetén több szelént vesznek fel a növények, mint szelenit-kijuttatáskor.

$\mathrm{Az}$ 1. táblázat a szareptai mustár és takarmányretek kultúrák szárazanyaghozamát is szemlélteti. Az adatok és a statisztikai elemzés alapján nyilvánvaló, hogy a szelenátkezelés jóval nagyobb mértékben csökkentette mindkét növényfaj szárazanyag-felhalmozását, mint a szelenit-kijuttatás. A szelenát-kezelt talajban nevelt szareptai mustár és takarmányretek gyökerében ez a csökkenés 85 , illetve $53 \%$-os, a hajtásokban 76, illetve 53\%-os volt a kontrollhoz viszonyítva. Mindez egyértelmüen a szelenátokból történő nagyobb szelénfelvétellel (1. táblázat) hozható kapcsolatba.

A rizoszférából vett, szelénnel szennyezett talajmintákban elsősorban Bacillus, Corynebacterium és Pseudomonas fajokat találtunk, melyek közül a Corynebacterium volt domináns (2. táblázat). A növények rizoszférájában talált mikrobacsoportokon belül a növénynövekedést serkentő (,plant-growth promoting rhizobacteria - PGPR") Pseudomonas és Bacillus fajokról feltételezhetjük, hogy a talajba kijuttatva a növények rizoszférájában serkentik a növények Se-fitoextrakcióját, illetve fitovolatizációját (DE SOUZA et al., 1999; ZHANG \& CHASTEEN, 1994).

Annak ellenére, hogy a nagyhörcsöki nehézfém-szennyezést tanulmányozó szabadföldi tartamkísérletben az 1991-ben kijuttatott Na-szelenit jelentős része idöközben a mélyebb rétegekbe mosódott le (KÁDÁR, 1999; KÁDÁR \& NÉMETH, 2003a,b; NÉMETH \& KÁDÁR, 2005; SIMON et al., 2006), 2005-ben a kezelt parcellákról betakarított lucerna hajtásában KÁDÁR (2006) 85,3-727 $\mu \mathrm{g} \cdot \mathrm{g}^{-1}$ szelént mért (3. táblázat). A jelentős szelénfelvételre magyarázatul szolgálhat, hogy időközben a szelenit nagy része a talajban a növények számára könnyebben felvehető szelenáttá alakult át (KÁDÁR, 1999; SzÉLES et al., 2006). A kísérleti parcellákon második éve termesztettek lucernát, mely mélyen gyökerezik, és feltételezhetően a mélyebb rétegekben is megtalálható szelénből (SIMON et al., 2006) is szállított fel szelént a hajtásába. A talaj legfelső $0-20 \mathrm{~cm}$-es rétegében a lemosódás ellenére is jelentős mennyiségű szelén maradt még, mely a kijuttatott Se-dózistól függően 2,3-8,0 


\section{2. táblázat}

Mikroorganizmusok százalékos megoszlása a szareptai mustár és takarmányretek szelénnel kezelt talajában (tenyészedény-kísérlet, Nyíregyháza, 2006)

\begin{tabular}{|c|c|c|c|c|c|c|}
\hline \multirow{3}{*}{$\begin{array}{c}\text { (1) } \\
\begin{array}{c}\text { Összmikroba-szám és } \\
\text { mikrobacsoport }\end{array} \\
\end{array}$} & \multicolumn{3}{|c|}{ (2) Szareptai mustár } & \multicolumn{3}{|c|}{ (4) Takarmányretek } \\
\hline & \multirow{2}{*}{$\begin{array}{c}(3) \\
\text { Kontroll }\end{array}$} & \multicolumn{2}{|c|}{$2,5 \mathrm{mg} \cdot \mathrm{kg}^{-1}$} & \multirow{2}{*}{$\begin{array}{c}\text { (3) } \\
\text { Kontroll }\end{array}$} & \multicolumn{2}{|c|}{$2,5 \mathrm{mg} \cdot \mathrm{kg}^{-1}$} \\
\hline & & $\mathrm{Na}_{2} \mathrm{SeO}_{3}$ & $\mathrm{Na}_{2} \mathrm{SeO}_{4}$ & & $\mathrm{Na}_{2} \mathrm{SeO}_{3}$ & $\mathrm{Na}_{2} \mathrm{SeO}_{4}$ \\
\hline $\begin{array}{l}\text { a) Összmikroba-szám } \\
\text { (CFU x 10\% /g talaj) }\end{array}$ & 23,3 & 126,3 & 106 & 96 & 78,6 & 198,4 \\
\hline Bacillus sp. (\%) & 22,3 & - & 4,9 & 7,7 & 9,5 & 18,4 \\
\hline $\begin{array}{l}\text { Corynebacterium sp. } \\
(\%)\end{array}$ & 77,7 & 53,6 & 94,8 & 92,0 & 86,5 & 80,5 \\
\hline Enterobacter sp. (\%) & - & 12,2 & - & - & - & - \\
\hline monas sp. $(\%)$ & - & & - & - & 3,6 & - \\
\hline Pseudomonas sp. (\%) & - & 23,8 & - & - & - & - \\
\hline Staphylococcus sp. (\%) & - & - & - & - & - & 1,1 \\
\hline b) Fonalas gomba (\%) & - & - & 0,3 & 0,3 & 0,4 & - \\
\hline
\end{tabular}

\section{3. táblázat}

Szeléntartalom a feltalajban $(0-20 \mathrm{~cm})\left(\mathrm{mg} \cdot \mathrm{kg}^{-1}\right)$ és a lucerna szénájában $\left(\mu \mathrm{g} \cdot \mathrm{g}^{-1}\right)$

15 évvel a Se talajba juttatása után

(Szabadföldi kisparcellás tartamkísérlet, Nagyhörcsök, 2005)

\begin{tabular}{|c|c|c|c|c|c|}
\hline \multirow{2}{*}{$\begin{array}{c}\text { Minta } \\
\text { Minta }\end{array}$} & \multicolumn{5}{|c|}{ Se-terhelés 1991 tavaszán, $\mathrm{kg} \cdot \mathrm{ha}^{-1}$} \\
\cline { 2 - 6 } & 0 & 30 & 90 & 270 & 810 \\
\hline a) Talaj (0-20 cm) & $0,41^{\mathrm{a}}$ & $2,3^{\mathrm{a}}$ & $4,6^{\mathrm{b}}$ & $8,4^{\mathrm{c}}$ & $8,0^{\mathrm{c}}$ \\
b) Lucernaszéna & $0,6^{\mathrm{a}}$ & $85,3^{\mathrm{ab}}$ & $298^{\mathrm{b}}$ & $616^{\mathrm{c}}$ & $727^{\mathrm{c}}$ \\
\hline
\end{tabular}

Megjegyzés: Varianciaanalízis. Tukey-féle b-teszt $(\mathrm{n}=2)$. Az azonos betüindexet kapott sorok értékei szignifikánsan nem különböznek egymástól $(\mathrm{P}<0,05)$.

$\mathrm{mg} \cdot \mathrm{kg}^{-1}$ között változott. A koncentrációhányadosok értéke a kontrollkultúrákban mindössze 1,5-szeres; 30, 90, 270 és $810 \mathrm{mg} \cdot \mathrm{kg}^{-1}$ Se-kijuttatás esetén 38-szoros, 65 szörös, 74-szeres és 91-szeres volt, vagyis lineárisan emelkedett. Minél több szelén volt tehát a feltalajban, annál több szelén került be a lucerna hajtásába. Mindez igazolja DUCKART és munkatársai (1992) azon megfigyeléseit, hogy a lucerna is a szelént jól akkumuláló növényfajok közé tartozik.

A kijuttatás utáni első négy évben a szelén erős fitotoxikus hatást gyakorolt a kísérleti parcellákon termesztett növényfajokra, majd 10 év elteltével (valószínűleg a szelén mélyebb rétegekbe történt kimosódásával összefüggésben) ez a terméscsökkentő hatás mérséklődött (KÁDÁR, 1999, 2006).

A szelén kimosódásával, illetve a talajban maradt szelénhez történt adaptációval magyarázható az is, hogy a kitenyészthető mikrobaszámokban (heterotrófok, spóra- 
képző mikrobák, sugárgombák és mikroszkopikus gombák) a kontroll- és a szelénkezelt talajok között nem találtunk szignifikáns eltérést (1. ábra). A talajban lévő szelénmennyiséget tehát tolerálták a mikrobák. Különbséget csak a mikrobacsoportok átlagos számában találtunk, amely általában egy-egy nagyságrenddel különbözött. Az átlagos sejtszámok (CFU) sorrendben a következöképpen alakultak: heterotróf összcsíraszám 6,76; sugárgombák 6,26; spórások 5,73; mikroszkopikus gombák 4,78. A szelénnel szennyezett talajmintákból elsősorban Staphylococcus, Streptococcus, Actinomyces, Corynebacterium és Bacillus fajokat tudtunk izolálni.

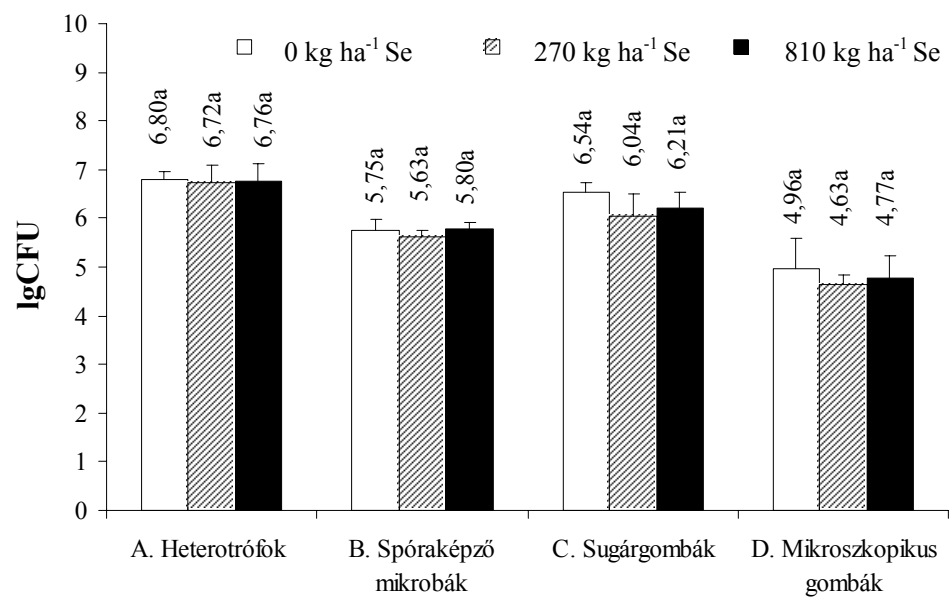

1. ábra

Néhány kitenyészthető mikroorganizmus-csoport átlagos sejtszámának (Colony Forming Units, CFU) logaritmusértékei 1 gramm száraz talajra vonatkoztatva a nagyhörcsöki kontroll- és szelénnel kezelt talajokban $(0-20 \mathrm{~cm})$. Megjegyzés: Varianciaanalízis. Tukey-féle bteszt $(n=6)$. Az azonos betüindexet kapott oszlopok értékei szignifikánsan nem különböznek egymástól $(\mathrm{P}<0,05)$

A 2. ábra a táplevesbe in vitro kijuttatott Na-szelenit hatását mutatja be a mikrobacsoportok szaporodására. A növekvő szeléndózisokkal a mikroszkopikus gombák és a heterotrófok száma csökkent ugyan, de ez nem bizonyult statisztikailag szignifikánsnak. Mivel a spóraképző mikrobák száma a 0,3 és 1,1 mM szeléndózis hatására szignifikánsan lecsökkent a kontrollhoz viszonyítva, feltételezhető, hogy a négy megvizsgált mikrobacsoport közül a spóraképzök a legérzékenyebbek a szelénfeleslegre. 


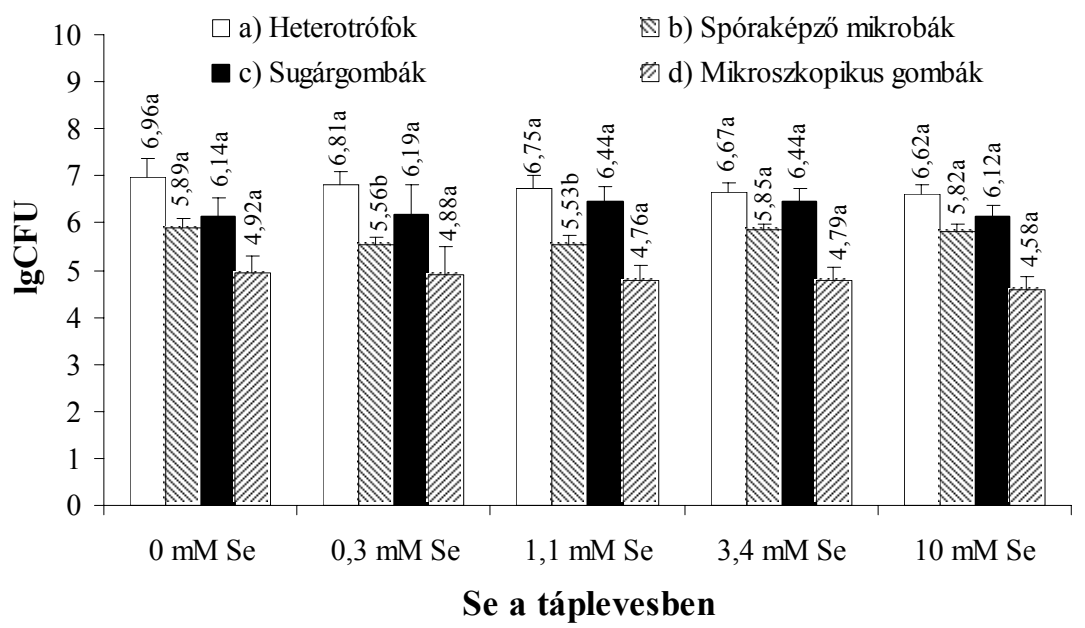

2. ábra

Szelén (Na-szelenit) hatása néhány mikrobacsoport szaporodására Nutrient táplevesben 14 órás rázatásos fermentáció után (in vitro kísérlet, Budapest, 2005). Megjegyzés: Varianciaanalízis. Tukey-féle b-teszt $(n=6)$. Az eltérő betüindexet kapott oszlopok értékei szignifikánsan különböznek egymástól $(\mathrm{P}<0,05)$

\section{Összefoglalás}

Tenyészedényes kísérletben tanulmányoztuk, hogy a Ramann-féle rozsdabarna erdőtalajba kijuttatott nátrium-szelenitből $\left(2,5 \mathrm{mg} \cdot \mathrm{kg}^{-1} \mathrm{Se}\right)$, illetve nátriumszelenátból $\left(2,5 \mathrm{mg} \cdot \mathrm{kg}^{-1} \mathrm{Se}\right)$ mennyi szelént akkumulál hajtásában a szareptai mustár és a takarmányretek. Megállapítottuk, hogy szelenit-kijuttatás esetén a hajtásba egy nagyságrenddel kevesebb szelén kerül be, mint a talaj szelenátkezelése esetén. Utóbbi esetben a szareptai mustár hajtásában 585 , a takarmányretekében $684 \mu \mathrm{g} \cdot \mathrm{g}^{-1}$ szelént mértünk. Mindez a hajtások szárazanyag-hozamának 53-85\%-os visszaesését eredményezte. A transzport indexek kiszámításával megállapítottuk, hogy a növények által felvett szelén 40-50\%-a szállítódott át a fitoextrakció során könnyen betakarítható hajtásba. A rizoszférából vett talajmintákban a domináns faj a Corynebacterium volt. A rizoszférában szintén jelen lévő Bacillus és Pseudomonas fajokról feltételezhetjük azonban - melyek a növénynövekedést serkentő ún. PGPR baktériumok közé tartoznak -, hogy a talajba mesterségesen kijuttatva stimulálják a növények szelénfelvételét (fitoextrakcióját), illetve fitovolatizációját.

A nagyhörcsöki mikroelem-terheléses szabadföldi tartamkísérletben a mészlepedékes csernozjom talajba 1991-ben $30-810 \mathrm{~kg} \cdot \mathrm{ha}^{-1}$ nátrium-szelenitet juttattak ki. A kijuttatott szelén nagy része időközben a mélyebb rétegekbe mosódott le, és szelenáttá oxidálódott. Annak ellenére azonban, hogy a szelénkezelt parcellák 0-20 cm-es rétegében mindössze 2,3-8,0 mg $\mathrm{kg}^{-1}$ volt az „összes" (cc. $\mathrm{HNO}_{3}+\mathrm{cc} . \mathrm{H}_{2} \mathrm{O}_{2}$ oldható) szeléntartalom, a lucerna hajtásában 2005 öszén $85,3-727 \mu \mathrm{g} \cdot \mathrm{g}^{-1}$ szelént 
mértünk. A koncentrációhányadosok kiszámolásával megállapítottuk, hogy a talaj szeléntartalmának növekedésével lineárisan nőtt a lucerna hajtásába került szelénmennyiség. A feltalajból kitenyészthető mikrobák (heterotrófok, spóraképzők, sugárgombák és mikroszkopikus gombák) átlagos sejtszáma még a legnagyobb (270 vagy $810 \mathrm{~kg} \cdot \mathrm{ha}^{-1}$ ) szelénkezelésben részesült parcellák talajában sem csökkent szignifikáns mértékben. Ezekben a talajmintákban Staphylococcus, Streptococcus, Actinomyces, Corynebacterium és Bacillus fajokat azonosítottuk.

Kulcsszavak: szelén, szennyezett talaj, fitoextrakció, mikrobacsoportok

A fenti munkát az OTKA T43479 és T46610 kutatási programok, az első szerző tevékenységét az OM Széchényi István ösztöndíja támogatta.

\section{Irodalom}

AdrianO, D. C., 2001. Trace Elements in Terrestrial Environments. Biogeochemistry, Bioavailability and Risks of Metals. $2^{\text {nd }}$ ed. Springer-Verlag. New York.

ANGERER, I. et al., 1998. Indicator microbes of chlorsulfuron addition detected by a simplified soil dilution method. Agrokémia és Talajtan. 47. 297-305.

BAÑUElos, G. S. \& MEEK, D. W., 1990. Accumulation of selenium in plants grown on selenium-treated soil. J. Environ. Qual. 19. 772-777.

Bañuelos, G. S., MeEK, D. W. \& Hoffman, G. J., 1990. The influence of selenium, salinity, and boron on selenium uptake of wild mustard. Plant Soil. 127. 201-206.

BarceleouX, D. G., 1999. Selenium. J. Toxicol. - Clin. Toxic. 37. 145-172.

DE SOUZA, M.P. et al., 1999. Rhizosphere bacteria enhance selenium accumulation and volatization by Indian mustard. Plant Physiol. 119. 565-573.

Duckart, E. C., Waldron, L. J. \& Donner, H. E., 1992. Selenium uptake and volatization from plants growing in soil. Soil Sci. 53. 94-99.

HEGEdüs, O. et al., 2005. Szeléntartalom növelése a borsó (Pisum sativum L.) magjának protein frakciójában a talajba kijuttatott szelénsókkal. Bull. Food Res. 44. 249-259. (Szlovák nyelven)

Kabata-Pendias, A. \& Pendias, H., 2001. Trace Elements in Soils and Plants. $3^{\text {rd }}$ ed. CRC Press LLC, Boca Raton-London-New York-Washington, D. C.

KÁDÁR I., 1999. Szelénforgalom a talaj-növény rendszerben. Agrokémia és Talajtan. 48. 233-242.

KÁDÁR I., 2006. Mikroelem-terhelés hatása a lucernára karbonátos csernozjom talajon. Kézirat. MTA TAKI. 1-18.

KÁDÁR I. \& NÉMETH T., 2003a. Mikroelem-szennyezők kimosódásának vizsgálata szabadföldi terheléses tartamkísérletben. Agrokémia és Talajtan. 52. 315-330.

KÁDÁR I. \& NÉMETH T., 2003b. Mikroelemek kilúgzása meszes csernozjom talajon. In: Mikroelemek a táplálékláncban (szerk.: SIMON L. \& SzILÁGYI M.). 134-149. Bessenyei György Könyvkiadó. Nyíregyháza. 
KovÁCS, B. et al., 2000. Studies on soil sample preparation for inductively coupled plasma atomic emission spectrometry analysis. Comm. Soil Sci. Plant Anal. 31. 1949-1963.

NÉMETH, T. \& KÁDÁR, I., 2005. Leaching of microelement contaminants: a long-term field study. Z. Naturforsch. 6Oc. 260-264.

SIMON L., 2004. Fitoremediáció. Környezetvédelmi Füzetek. BMKE OMIKK. Budapest.

SiMON, L. et al., 2006. Phytoextraction of selenium from contaminated soils with Indian mustard, fodder radish and alfalfa. In: Proc. Internat. Symp. on Trace Elements in the Food Chain. (Eds.: SzILÁgyi, M. \& SzentMihÁlyi, K.). 40-44. Working Committee on Trace Elements of the Complex Committee Hungarian Academy of Sciences and Institute of Material and Environmental Chemistry of the Hungarian Academy of Sciences. Budapest, Hungary.

SimON, L., SZEGVÁRI, I. \& CSILlAG, J., 2003. Impact of picolinic acid on the chromium accumulation in fodder radish and komatsuna. Plant Soil. 254. 337-348.

SZABÓ S.A., GYÖRi D. \& REGIUSNÉ M. Á., 1993. Mikroelemek a mezőgazdaságban II. (Stimulatív hatású mikroelemek). Akadémiai Kiadó és Nyomda. Budapest.

SzEGI J. 1976. Talajmikrobiológiai vizsgálati módszerek. Mezőgazdasági Kiadó. Budapest.

SzÉLES É. et al., 2006. Szelén-speciációs vizsgálatok talajmintákból ionkromatográffal összekapcsolt induktív csatolású plazma-tömegspektrométer (IC-ICP-MS) alkalmazásával. Debreceni Egyetem Agrártudományi Közlemények. Acta Agraria Debreciensis. Különszám. 23. 106-111.

Terry, N. et al., 2000. Selenium in higher plants. Annu. Rev. Plant Physiol. Plant Mol. Biol. 51. 401-432.

Terry, N. \& BAÑuelos, G. (Eds.), 2000. Phytoremediation of Contaminated Soil and Water. Lewis Publishers. Boca Raton-London-New York-Washington, D. C.

VINCZE, G. et al., 1994. Investigation of chromium(VI) tolerant bacteria. Acta Biol. Hung. 45. 17-25.

VIVAS, A et al., 2003. Beneficial effects of indigenous Cd-tolerant and Cd-sensitive Glomus mossae associated with a Cd-adapted strain of Brevibacillus sp. in improving plant tolerance to Cd contamination. Appl. Soil Ecol. 24. 177-186.

Xie, H., PAternak, J. J. \& Glick, B. R., 1996. Isolation and characterisation of mutants of the plant growth promoting rhizobacteria Pseudomonas putida $\mathrm{Gr}-12-2$ that overproduce indole acetic acid. Curr. Microbiol. 32. 67-11.

Zayed, A., Lyttle, C. M. \& Terry, N., 1998. Accumulation and volatization of different chemical species of selenium by plants. Planta. 206. 284-292.

ZHANG, L. \& CHASTEEN, T.G., 1994. Amending cultures of selenium-resistant bacteria with dimethyl selenone. Appl. Organomet. Chem. 8. 501-508.

Érkezett: 2006. szeptember 19. 


\title{
Phytoextraction of selenium and occurrence of microbial groups in contaminated soils
}

\author{
${ }^{1 \mathrm{a}}$ L. SIMON, ${ }^{2}$ B. BIRÓ, ${ }^{3}$ É. SZÉLES and ${ }^{1 \mathrm{~b}}$ S. BALÁZSY \\ ${ }^{1 \mathrm{a}}$ Department of Land and Environmental Management, ${ }^{\mathrm{b}}$ Institute of Biology, College of \\ Nyíregyháza; ${ }^{2}$ Research Institute for Soil Science and Agricultural Chemistry of the Hungarian \\ Academy of Sciences, Budapest and ${ }^{3}$ Department of Food Science and Technology Centre of \\ Agricultural Sciences, University of Debrecen (Hungary)
}

\begin{abstract}
Summary
A pot experiment was set up to study the selenium (Se) accumulation of Indian mustard (Brassica juncea L. Czern., cv. Negro Caballo) and fodder radish (Raphanus sativus L. convar. oleiformis Pers., cv. Leveles olajretek) grown in a Ramann-type rusty brown forest soil (loamy sand, clay+silt content $15.8 \% ; \mathrm{pH}(\mathrm{KCl}) 6.6$; humus content $1.3 \%$; CEC $18.1 \mathrm{cmol}_{\mathrm{c}} \cdot \mathrm{kg}^{-1}$ ) artificially contaminated with $2.5 \mathrm{mg} \cdot \mathrm{kg}^{-1} \mathrm{Se}$ as sodium selenite or sodium selenate. Plant shoots accumulated one order of magnitude less selenium from selenite than from selenate-treated soil. In shoots of selenate-treated Indian mustard and fodder radish cultures 657 and $745 \mu \mathrm{g} \cdot \mathrm{g}^{-1} \mathrm{Se}$ was measured respectively, while the dry matter yield of the plants was reduced by $53-85 \%$. Based on transport indexes it was calculated that $40-50 \%$ of the total Se was accumulated in the plant shoots. This could be advantageous, as the shoots of plants are easier to harvest than the roots during soil remediation with plants, known as phytoextraction. The dominant microbe species was Corynebacterium in the rhizosphere soil, and Bacillus and Pseudomonas species were also present. It is supposed that these "plant-growth promoting rhizobacteria" (PGPR) may stimulate the phytoextraction and phytovolatization of Se in the rhizosphere of the plants.

In spring 1991 a field experiment was set up in Nagyhörcsök (Hungary) to study the long-term effects of 13 heavy metals. The calcareous chernozem formed on loess $\mathrm{pH}_{\mathrm{KCl}}$ 7.1-7.4, loamy texture, clay+silt content 75-85\%; humus 3-3.5\%; $\mathrm{CaCO}_{3}$ equivalent 3$5 \%$; CEC 30-32 cmolc $\cdot \mathrm{kg}^{-1}$ ) was contaminated with $0,30,90,270$ or $810 \mathrm{~kg} \mathrm{Se} \cdot \mathrm{ha}^{-1}$ as sodium selenite. Over the course of time the selenite migrated downward (leached) and oxidized to selenate. In autumn $20052.3-8.0 \mathrm{mg} \cdot \mathrm{kg}^{-1}$ "total" (extracted with cc. $\left.\mathrm{HNO}_{3}+\mathrm{cc} . \mathrm{H}_{2} \mathrm{O}_{2}\right)$ selenium was found in the upper $(0-20 \mathrm{~cm})$ layer of soil. Based on concentration ratios it was found that with increasing soil Se content the Se content in the shoots of alfalfa (Medicago sativa L., cv. Anna) increased linearly (85.3-727 $\left.\mu \mathrm{g} \cdot \mathrm{g}^{-1}\right)$. This could be attributed to the deep rooting of alfalfa. All the microbe groups (heterothrophs, spore forming microbes, actinomyceta and microscopic fungi) investigated tolerated the Se concentrations present in the contaminated soils, as their number was similar to that in the uncontamined control soil. In Se-contaminated soils the dominant microbe species were Staphylococcus, Streptococcus, Actinomyces, Corynebacterium and Bacillus.
\end{abstract}

Table 1. Selenium accumulation and dry matter yield of Indian mustard and fodder radish (pot experiment, Nyíregyháza, 2006). (1) Treatments. a) Control. b) $2.5 \mathrm{mg} \cdot \mathrm{kg}^{-1}$ Na-selenite. c) $2.5 \mathrm{mg} \cdot \mathrm{kg}^{-1}$ Na-selenate. (2) Indian mustard. (3) Root. (4) Shoot. (5) Fodder radish. A. Selenium accumulation $\left(\mu \mathrm{g} \mathrm{Se} \cdot \mathrm{g}^{-1}\right.$ dry matter). B. Dry matter 
$\left(\mathrm{g} \cdot \mathrm{plant}^{-1}\right)$. Remarks: Analysis of variance. Tukey's b-test $(\mathrm{n}=4)$. Data within column groups designated by the same letter are not significantly different at $\mathrm{P}<0.05$.

Table 2. Percentage distribution of microbes in the control and Se-treated soils of Indian mustard and fodder radish (pot experiment, Nyíregyháza, 2006). (1) Total number of microbes and microbe groups. a) Total number of microbes (CFU $\times 10^{6} / \mathrm{g}$ soil). b) Filamentous fungi. (2) Indian mustard. (3) Control. (4) Fodder radish.

Table 3. Selenium content in the upper soil layer $(0-20 \mathrm{~cm})\left(\mathrm{mg} \cdot \mathrm{kg}^{-1}\right)$ and in the hay of alfalfa $\left(\mu \mathrm{g} \cdot \mathrm{g}^{-1}\right) 15$ years after the application of Se (small plot long-term field experiment, Nagyhörcsök, 2005). (1) Sample. a) Soil (0-20 cm), b) alfalfa hay. (2) Selenium treatment in spring 1991, $\mathrm{kg} \cdot \mathrm{ha}^{-1}$. Remarks: Analysis of variance. Tukey's b-test $(\mathrm{n}=2)$. Data within rows designated by the same letter are not significantly different at $\mathrm{P}<0.05$.

Fig. 1. Logarithmic values of the average number of microbes (Colony Forming Units) based on $1 \mathrm{~g}$ of dry soil in the control and Se-treated upper soil layers $(0-20 \mathrm{~cm})$ from Nagyhörcsök. Remarks: Analysis of variance. Tukey's b-test $(\mathrm{n}=6)$. Data within column groups designated by the same letter are not significantly different at $\mathrm{P}<0.05$. Horizontal axis: (from left to right): heterotrophs, spore-forming microbes, actinomyceta and microscopic fungi.

Fig. 2. Effect of Se (sodium selenite) on the average number of microbe groups in nutrient broth after 14 hours of fermentation with shaking (in vitro experiment, Budapest, 2005). Remarks: Analysis of variance. Tukey's b-test $(\mathrm{n}=6)$. Data within column groups designated by different letters are significantly different at $\mathrm{P}<0.05$. From top to bottom: heterotrophs, spore-forming microbes, actinomyceta and microscopic fungi. Horizontal axis: Se in broth. 